\title{
Perilaku migrasi Sikep-Madu Asia dalam pemanfaatan lanskap di Flores bagian timur, Indonesia berdasarkan data satellite-tracking
}

\section{Migratory behavior in landscape utilization by oriental honey-buzzard based on satellite tracking data in East Flores, Indonesia}

Syartinilia ${ }^{\mathrm{a}}$, Risco Noverio Rafael ${ }^{\mathrm{a}}$, Hiroyoshi Higuchi ${ }^{\mathrm{b}}$

a Departemen Arsitektur Lanskap, Fakultas Pertanian, IPB University, Kampus IPB Darmaga Bogor, 16680, Indonesia [+62-251-8422415]

${ }^{\mathrm{b}}$ Research and Education Center for Natural Sciences, Keio University, Hiyoshi 4-1-1, Yokohama, Kaganawa, Japan [223-8521]

\section{Article Info:}

Received: 21 - 06 - 2020

Accepted: $07-09$ - 2020

\section{Keywords:}

Satellite-tracking, stepping stone, small islands, migratory behavior, Pernis ptylorhynchus

Corresponding Author: Syartinilia

Departemen Arsitektur Lanskap,

Fakultas Pertanian, IPB

University;

Tel. +62-251-8422415

Email:

syartinilia@apps.ipb.ac.id

\begin{abstract}
Raptor migration is complex phenomenon of migration which involving of millions of individual birds flying hundreds or thousands kilometers, between breeding habitat and wintering habitat. Migratory behavior consisted of period, route, and other aspects that affect the ecology of migratory birds. Pernis ptylorhynchus, Oriental honey-buzzard $(\mathrm{OHB})$ is one of migratory raptor which have satellite tracked by ARGOS since 2003. Eastern part of Flores Islands consisted of small islands (23 islands) were identified as OHB's migratory path to reach their wintering habitats in Timor Island. This study aimed to identify and analyze the OHB's migratory behavior in Eastern part of Flores Islands. Four individuals OHB have satellite tracked in the period of 2007-2012 were used as main data for analyzing their migratory behavior. There was no particular pattern found on the way of OHBs selected islands for their stopover site because of the existence of small islands cluster provide variety of route for each OHBs. The length of their stay found relatively constant every year and tend to be stay longer on larger islands than the smaller one such as Flores Island and Lembata Island. This is apparently due to the larger islands provide more food supply than smaller islands.
\end{abstract}

How to cite (CSE Style $8^{\text {th }}$ Edition):

Syartinilia, Rafael RN, Higuchi H. 2020. Perilaku migrasi Sikep-Madu Asia dalam pemanfaatan lanskap di Flores bagian timur, Indonesia berdasarkan data satellite-tracking. JPSL 10(3): 479-488. http://dx.doi.org/10.29244/jpsl.10.3.479-488.

\section{PENDAHULUAN}

Indonesia merupakan negara kepulauan terbesar di dunia dengan jumlah pulau mencapai 17504 pulau yang menyebar sepanjang garis pantai $81000 \mathrm{~km}$. Berdasarkan potensi tersebut, pulau-pulau ini memiliki nilai penting dan tergolong unik bila ditinjau dari sisi sumber daya alam, geografi, sosial, ekonomi, budaya, politik, dan pertahanan keamanan Indonesia (Bengen et al., 2006). Berdasarkan data satellite-tracking diketahui bahwa keberadaan pulau-pulau kecil memiliki peran penting dalam perjalanan migrasi Sikep-madu Asia yaitu sebagai habitat singgah (stepping stone) (Syartinilia et al., 2016) sebelum melanjutkan perjalanan menuju lokasi habitat musim dinginnya (wintering habitat) yang merupakan pulau-pulau besar di Indonesia (Syartinilia et al., 2015). 
Satellite-tracking merupakan alat yang sangat ampuh untuk menginvestigasi pergerakan hewan khususnya bagi hewan yang melakukan pergerakan dengan skala global (Cohn, 1999; Webster et al., 2002; Higuchi et al., 2004). Sejak tahun 2003 terdapat sebanyak 59 individu burung Sikep-madu Asia yang telah diikuti jejaknya dengan menggunakan satelit ARGOS. Sikep-madu Asia melakukan migrasi dari habitat berkembang biak (breeding habitat) yang berada di Jepang ke habitat musim dingin (wintering habitat) yang berada di Filipina, Malaysia, Indonesia, dan Timor Leste. Berdasarkan perjalanan migrasinya maka dikelompokkan menjadi dua, yaitu autumn migration (migrasi musim gugur) yang merupakan perjalanan migrasi dari habitat berkembang biak menuju habitat musim dingin, sedangkan migrasi musim semi (spring migration) merupakan perjalanan migrasi dari habitat musim dingin kembali menuju habitat berkembangbiak (Bildstein, 2006). Nusa Tenggara Barat, Nusa Tenggara Timur, dan Pulau Timor merupakan bagian besar dari Kepulauan Sunda Kecil yang merupakan habitat musim dingin Sikep-madu Asia yang terbesar setelah pulau Kalimantan (Syartinilia et al., 2015, 2016). Flores bagian timur merupakan bagian dari Provinsi Nusa Tenggara Timur (NTT) yang menjadi lokasi persebaran habitat singgah Sikep-madu Asia. Berdasarkan data satellitetracking terdapat empat individu Sikep-madu Asia yang melewati Flores bagian timur (2007-2012) untuk menuju ke habitat musim dinginnya di Pulau Timor. Selain Sikep-madu Asia, Flores bagian timur juga menjadi jalur yang dilewati raptor lain untuk bermigrasi. Elang Alap Cina dan Elang Alap Jepang merupakan jenis dari raptor migran yang juga melintasi kawasan tersebut (YKEI, 2014). Kawasan Flores bagian timur juga memiliki iklim yang unik dibandingkan dengan kawasan Indonesia bagian barat. Fakta ini membuktikan bahwa kawasan tersebut memiliki nilai ekologi yang tinggi.

Selain potensi yang ada pada kawasan Flores bagian timur, terdapat juga kendala yang dihadapi secara umum seperti pada pulau-pulau kecil di Indonesia lainnya. Permasalahan pulau kecil yang umum terjadi antara lain pulau yang terletak di perbatasan antar daerah dan antar negara, pulau-pulau kecil yang terancam tenggelam atau hilang, pulau-pulau kecil pasca tambang, serta pulau-pulau kecil berpotensi konflik cukup tinggi (Husni, 1998). Gangguan lanskap yang cukup tinggi di Flores bagian timur adalah terjadinya abrasi yang besar di berbagai tempat di Flores bagian timur. Berdasarkan potensi dan kendala yang terdapat pada pulaupulau kecil, maka pulau-pulau kecil penting untuk dijaga kelestariannya. Gangguan dan permasalahan yang terjadi pada pulau kecil dapat menyebabkan rusaknya lanskap, serta hilangya jalur migrasi raptor. Penelitian ini bertujuan untuk mengidentifikasi dan menganalisis perilaku migrasi Sikep-madu Asia di Flores bagian timur dengan menggunakan data satellite tracking (2007-2012). Perilaku migrasi yang dimaksud merupakan perilaku Sikep-madu Asia selama melakukan periode migrasi musim gugur maupun musim semi yang bisa dideteksi dari rekam jejak perjalanannya menggunakan satellite-tracking. Adapun perilaku yang akan dianalisis adalah dalam kaitan pola pemilihan pulau sebagai habitat singgah dan juga periode singgah yang meliputi frekuensi singgah dan durasi waktu singgahnya.

\section{METODE}

\section{Lokasi dan Waktu Penelitian}

Penelitian ini dilakukan di kawasan Flores bagian timur, Nusa Tenggara Timur, Indonesia (Gambar 1). Lokasi penelitian berada pada tiga kabupaten yaitu Kabupaten Sikka, Kabupaten Flores Timur, dan Kabupaten Lembata yang terdiri dari 23 pulau. Pulau-pulau tersebut mempunyai ukuran dari yang terkecil sekitar 0.013 $\mathrm{km}^{2}$ hingga $2601.99 \mathrm{~km}^{2}$. Terdapat 13 pulau dengan ukuran kecil dari $1 \mathrm{~km}^{2}$ dan sisanya adalah pulau dengan ukuran 1 hingga $7 \mathrm{~km}^{2}$ (lima pulau) dan besar dari $7 \mathrm{~km}^{2}$ (lima pulau). Lima pulau dengan ukuran terbesar adalah Pulau Flores $\left(2601.99 \mathrm{~km}^{2}\right)$, Pulau Lembata $\left(1273.48 \mathrm{~km}^{2}\right)$, Pulau Adonara $\left(514.17 \mathrm{~km}^{2}\right)$, Pulau Solor $\left(222.68 \mathrm{~km}^{2}\right)$, Pulau Kojadoi $\left(53.51 \mathrm{~km}^{2}\right)$. Sementara itu, pulau dengan ukuran terkecil adalah Pulau Keroko $\left(0.013 \mathrm{~km}^{2}\right)$. 


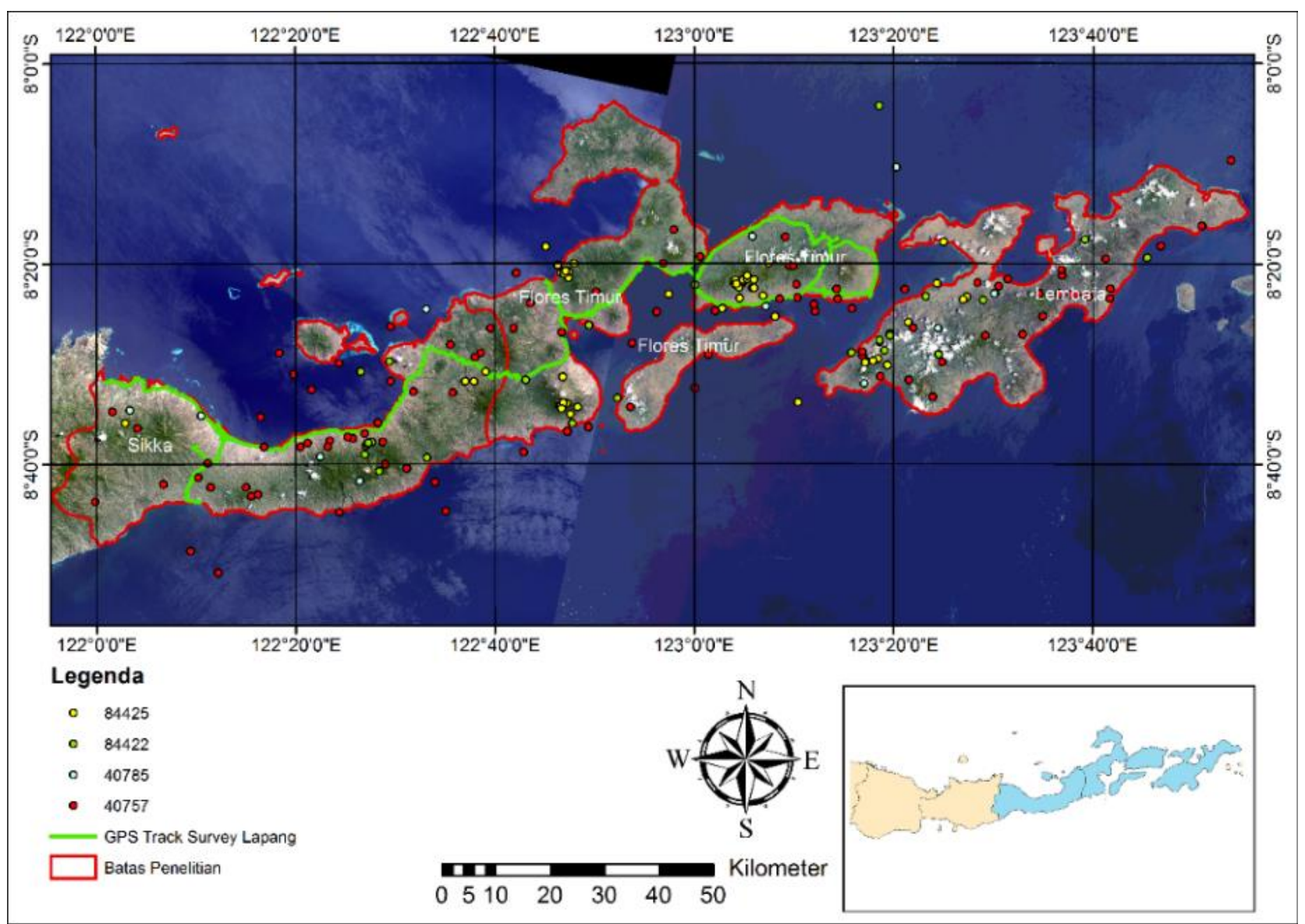

Gambar 1 Lokasi penelitian (Sumber: Citra Landsat 8 (September 2015 dan November 2015))

\section{Metode Pengumpulan Data}

Metode penelitian ini terdiri atas beberapa tahap yaitu inventarisasi, analisis, dan sintesis. Tahap inventarisasi meliputi kegiatan pengumpulan data (spasial dan non spasial) dan survei untuk melakukan ground check lokasi yang menjadi habitat singgah Sikep-madu Asia di Flores bagian Timur. Pada tahap survei lapang dilakukan pengamatan secara langsung, dokumentasi lapang serta wawancara dengan pihak terkait.

\section{Alat dan Bahan}

Alat yang digunakan dalam penelitian adalah kamera, binokuler, GPS, dan perangkat lunak untuk analisis spasial yaitu ArcGIS 9.3 dan ERDAS Imagine 2014. Adapun data yang digunakan pada penelitian disajikan pada Tabel 1. Penelitian ini menggunakan data satellite-tracking dari empat individu Sikep-madu Asia yang melakukan migrasi dari habitat berkembang biak di Jepang menuju habitat musim dingin di Pulau Timor baik dalam migrasi musim gugur (Oktober-Januari) maupun migrasi musim semi (Februari-Mei) dari tahun 2007 hingga 2012 (Gambar 2).

Tabel 1 Jenis, bentuk, sumber, dan kegunaan data

\begin{tabular}{clll}
\hline No & \multicolumn{1}{c}{ Jenis } & \multicolumn{1}{c}{ Bentuk } & \multicolumn{1}{c}{ Sumber } \\
\hline 1 & Batas Administrasi & Vektor & 1.1.1. http://diva-gis.org \\
2 & Data Satellite-tracking & Vektor, Titik (Nomor Platform: & ARGOS 2007 - 2012 \\
& Individu Sikep-madu Asia & 40757, 40875, 84422, dan 84425 ) & \\
3 & Tutupan Lahan & Raster, resolusi 30*30m & Landsat 8, \\
& & & http://earthexplorer.usgs.gov/ \\
\hline
\end{tabular}




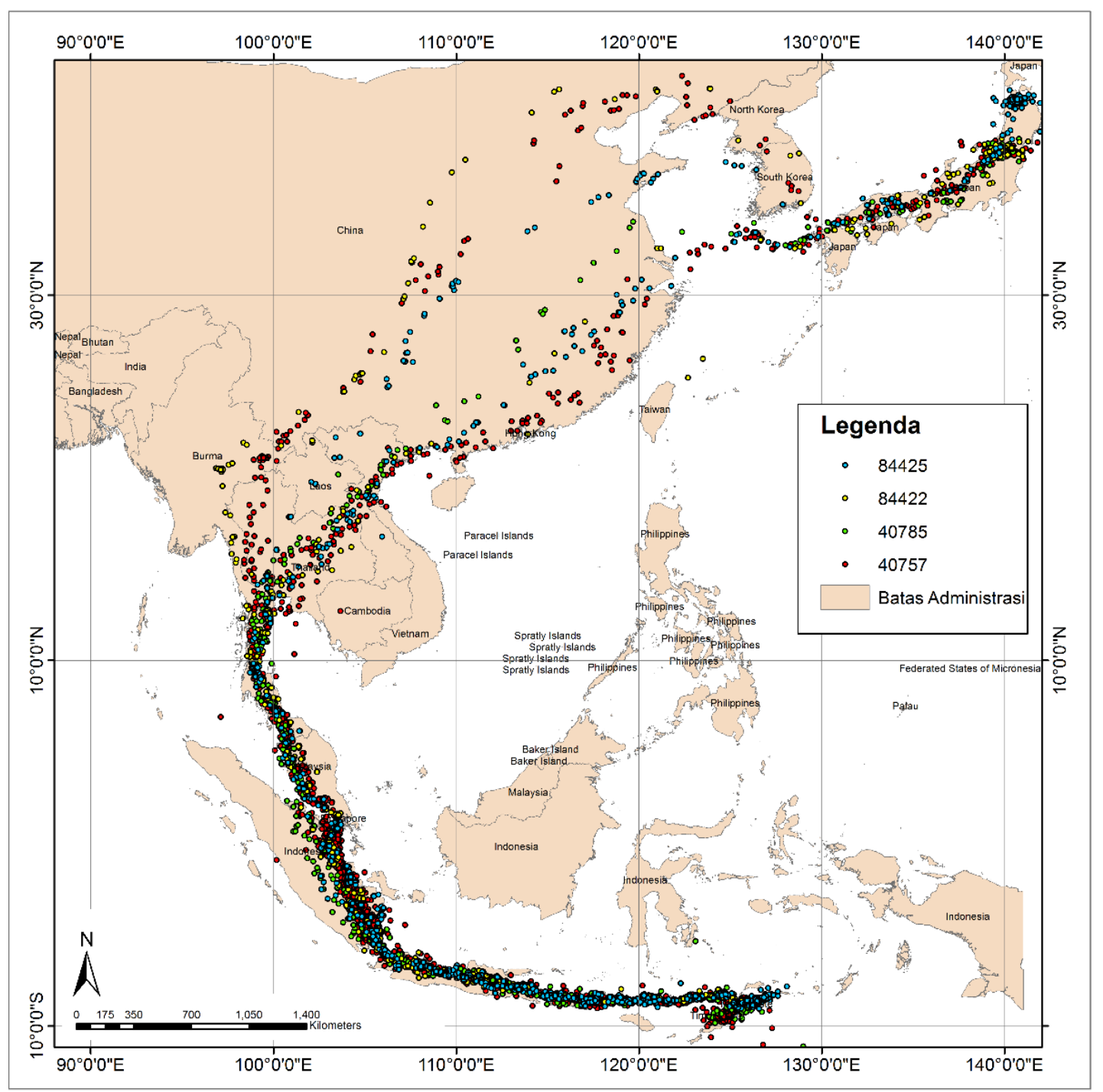

Gambar 2 Data satellite-tracking migrasi Sikep-madu Asia periode 2007-2012 (Sumber: ARGOS)

Data hasil satellite-tracking terdiri dari informasi lokasi dan waktu yang digunakan Sikep-madu Asia pada perjalanan autumn migration (migrasi musim gugur) dan spring migration (migrasi musim semi) dari habitat berkembang biak, habitat singgah, dan habitat musim dinginnya. Peta tutupan lahan dihasilkan dari analisis klasifikasi citra LANDSAT 8 dengan menggunakan metode klasifikasi terbimbing (Supervised Classification).

\section{Metode Analisis Data}

\section{Analisis Perilaku Singgah Sikep-madu Asia di Flores Bagian Timur}

Proses identifikasi perilaku singgah Sikep-madu Asia didasarkan pada preferensi di dalam perilaku pemilihan pulau untuk habitat singgah dan periode singgahnya 4 individu Sikep-madu Asia di 23 pulau-pulau yang ada di Flores bagian Timur. Dari data tersebut dengan menggunakan perangkat lunak Sistem Informasi Geografis (ArcGIS) dapat dipetakan lokasi singgah dari seluruh individu Sikep-madu Asia baik pada perjalanan migrasi musim semi maupun musim gugur. Analisis perilaku singgah juga dilakukan untuk mengetahui perbedaan perilaku singgah antara migrasi musim semi dan musim gugur. Kemudian data tersebut diolah menggunakan analisis statistika deskriptif. Peta tutupan lahan digunakan untuk mengetahui tutupan lahan yang ada pada 23 pulau. 


\section{Analisis Periode Singgah Sikep-madu Asia}

Pada analisis periode singgah Sikep-madu Asia, dilakukan pengambilan sampel data dari semua data satellite-tracking yang ada. Sampel yang diambil merupakan sampel dengan periode yang lengkap dari perjalanan Sikep-madu Asia dalam satu musim migrasi. Hal ini dilakukan untuk menyetarakan data yang ada agar dapat dilihat perbandingannya dalam melakukan analisis periode singgah. Tabel 2 menunjukkan data periode singgah yang diambil untuk dianalisis. Pada analisis ini akan diketahui frekuensi singgah dan durasi waktu singgah pada setiap pulau yang digunakan. Hasil analisis yang didapat dibandingkan dengan karakter lanskap dilhat dari tutupan lahannya.

Tabel 2 Sampel sattellite-tracking individu Sikep-madu Asia yang digunakan dalam analisis periode singgah

\begin{tabular}{cccc}
\hline \multirow{2}{*}{ No. } & No. Platform & \multicolumn{2}{c}{ Periode Migrasi (tahun) } \\
\cline { 3 - 4 } & Individu & Migrasi Musim Gugur (Okt-Jan) & Migrasi Musim Semi (Feb-Mei) \\
\hline 1 & 40785 & 2007 & 2008 \\
2 & 84422 & 2008 & 2009 \\
3 & 84425 & 2009 & 2010 \\
4 & 40757 & 2011 & 2012 \\
\hline
\end{tabular}

\section{HASIL DAN PEMBAHASAN}

Perilaku burung migran merupakan perilaku yang terjadi selama melakukan periode migrasi yang berdasarkan pada ekologi burung migran. Perilaku tersebut secara umum antara lain seperti waktu yang digunakan burung migran dalam bermigrasi, penggunaan jalur migrasi, cara burung migran mendapatkan arah dalam melakukan perjalanan, serta semua yang berkaitan dengan ekologi burung migran (Higuchi, 2016). Pada penelitian ini perilaku yang dilihat merupakan perilaku dalam pemilihan pulau sebagai habitat singgah dan juga periode singgah yang digunakan oleh Sikep-madu Asia. Dari hasil analisis pola pemilihan pulau yang digunakan sebagai habitat singgah menunjukkan bahwa hanya 30\% pulau (tujuh pulau) yang digunakan dalam bermigrasi oleh Sikep-madu Asia. Akan tetapi, 30\% tersebut luasnya adalah 99\% dari total luas keseluruhan kawasan Flores bagian timur. Gambar 3 menunjukkan pulau yang digunakan dan frekuensi singgah oleh semua individu Sikep-madu Asia dalam periode 2007-2012.

Saat periode migrasi musim gugur, P. Flores dan P. Adonara digunakan oleh semua individu untuk bermigrasi. Sedangkan P. Kojadoi dan P. Kojakecil hanya 25\% individu yang menggunakan pulau tersebut untuk migrasi musim gugur. Pada periode migrasi musim semi, P. Flores dan P. Lembata digunakan oleh semua individu untuk bermigrasi dengan nilai $100 \%$. Sedangkan P. Kojadoi hanya 25\% individu yang menggunakan pulau tersebut untuk migrasi musim semi. Hal ini menunjukkan bahwa Sikep-madu Asia memiliki kecenderungan untuk singgah pada pulau berukuran besar yaitu Pulau Flores, Lembata, Pulau Adonara, dan Pulau Kojadoi dalam perjalanan migrasi pada periode 2007-2012. Semua pulau dapat berpotensi sebagai stepping stone dalam jalur migrasi Sikep-madu Asia, dibuktikan oleh pulau dengan ukuran kecil sekalipun tetap ada rekam jejak penggunaannya. Hanya saja, kecenderungan frekuensi yang besar dalam penggunaan pulau berukuran besar $\left(>7 \mathrm{~km}^{2}\right)$. Hal ini terjadi sudah jelas karena pulau yang berukuran lebih besar memiliki sumber daya/daya dukung yang lebih banyak juga daripada pulau berukuran kecil.

Sikep-madu Asia melakukan perjalanan migrasi menuju habitat musim dingin di Pulau Timor, mempunyai rute perjalanan migrasi musim gugur (Gambar 4) maupun migrasi musim semi (Gambar 5) yang kalau menggunakan daratan sebagai jalur pergerakannya. Saat melewati Flores bagian timur, Sikep-madu Asia lebih memilih memutar melewati daratan dengan konsekuensi jarak yang lebih jauh yaitu $300 \mathrm{~km}$ dari Maumere menuju Pulau Timor dibandingkan kalau dengan menyeberangi lautan langsung yang hanya mempunyai jarak sekitar $200 \mathrm{~km}$. 


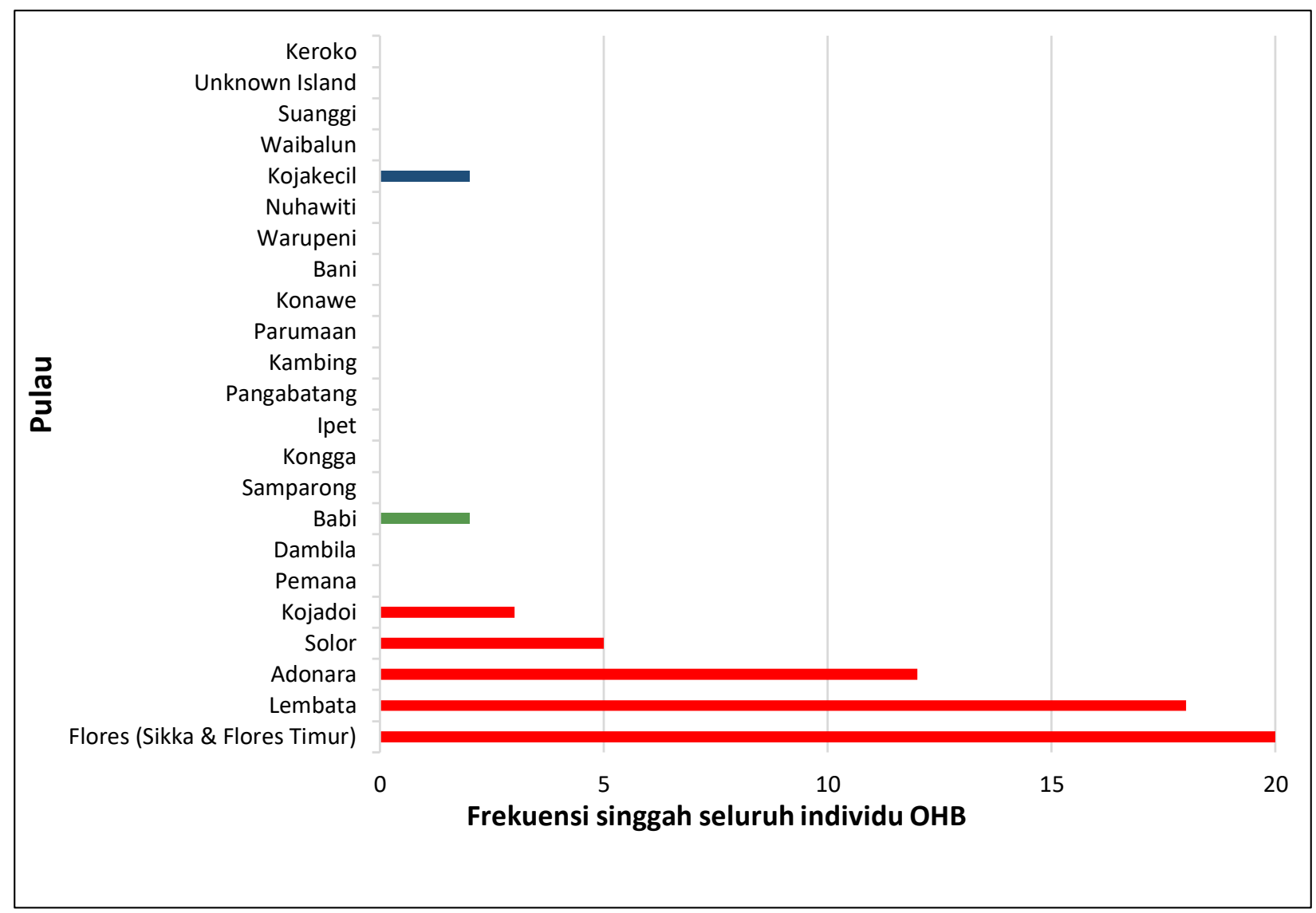

Gambar 3 Frekuensi singgah seluruh individu Sikep-madu asia dalam periode 2007-2012

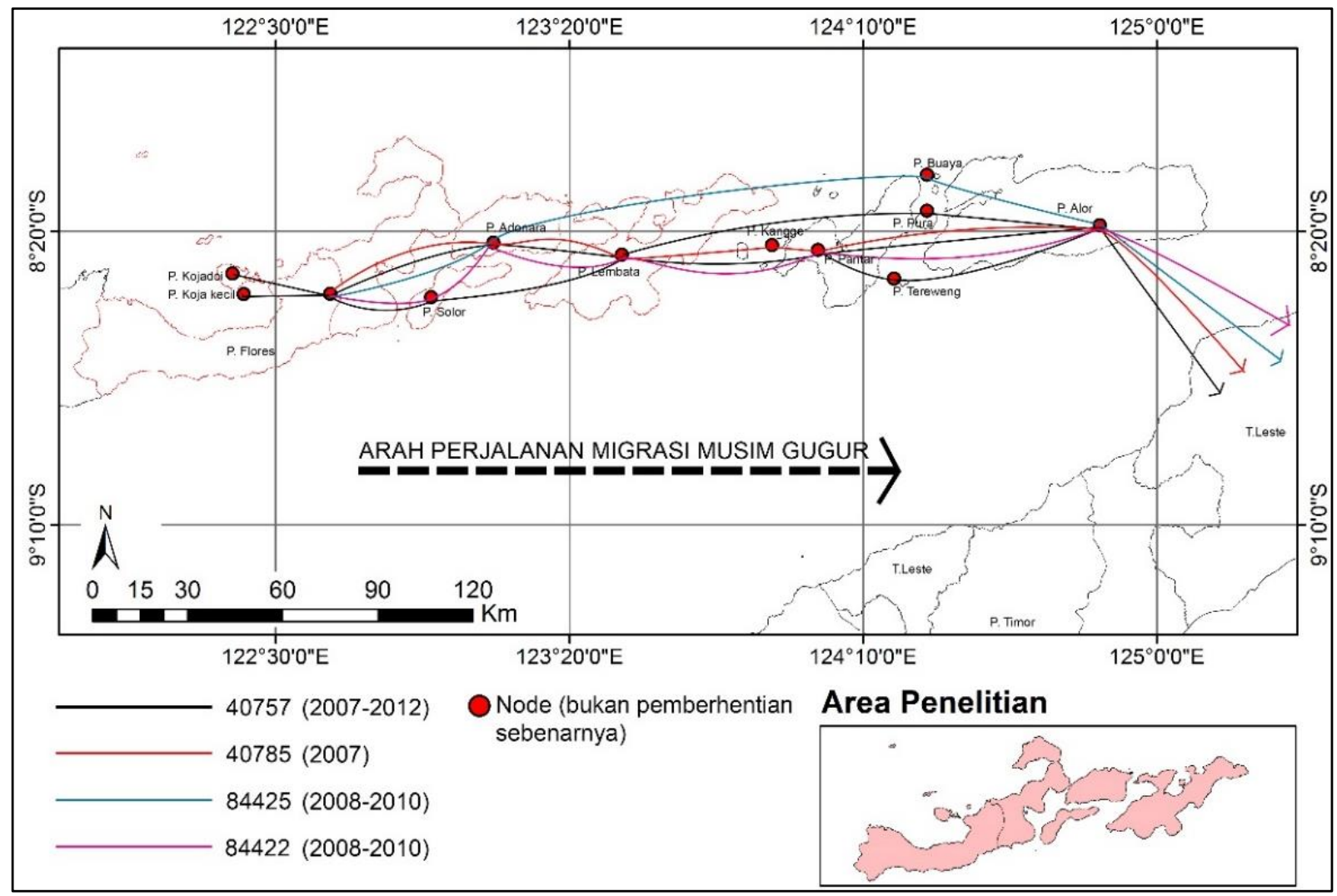

Gambar 4 Perjalanan migrasi musim gugur dalam periode 2007-2012 


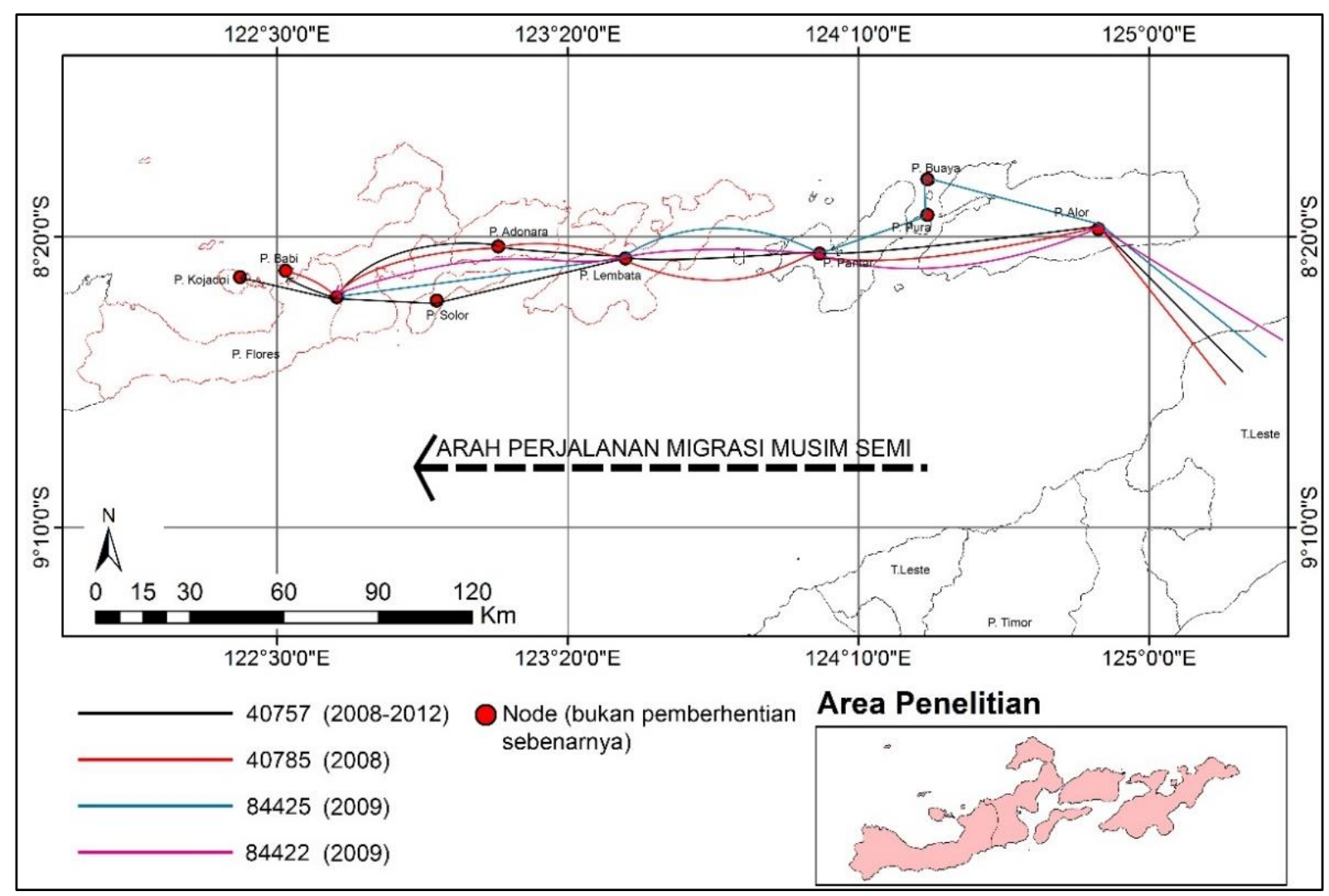

Gambar 5 Perjalanan migrasi musim semi dalam periode 2007-2012

Perilaku migrasi ini diduga sebagai strategi untuk keselamatan Sikep-madu Asia jika terjadi kondisi yang tidak diinginkan di dalam perjalanan serta untuk menghemat energi terbang dengan memanfaatkan energi angin termal yang dihasilkan oleh bentukan topografi yang ada di daratan, selain itu juga daratan merupakan tempat beristirahat dan mencari makan untuk memulihkan kembali energinya sebelum kembali melanjutkan perjalanan (Bildstein, 2006; Syartinilia et al., 2016). Pada saat melewati Flores bagian timur, rute singgah dari empat individu Sikep-madu Asia memiliki rute yang berbeda-beda. Kumpulan dari pulau-pulau kecil di Flores bagian timur dan sekitarnya dapat diumpamakan sebagai kumpulan stepping stone (Dramstad, 1996) yang menyediakan jalan alternatif untuk pergerakan antar pulau bagi Sikep-madu Asia.

Pada migrasi musim semi dan musim gugur, berdasarkan data satellite-tracking diketahui periode singgah Sikep-madu Asia di Flores bagian timur adalah 1 sampai dengan 4 hari (Tabel 3). Kemudian dari periode singgah tersebut diidentifikasi bahwa durasi singgah terlama ditemukan pada Pulau Lembata dan Pulau Flores terutama untuk individu 84425, 84422, dan 40757. Durasi singgah terlama ditemukan pada Pulau Lembata namun oleh individu yang berbeda yaitu 41 jam pada migrasi musim gugur (individu 40757) yang dan 28 jam pada migrasi musim semi (individu 84422). Perbedaan durasi singgah saat migrasi musim semi dan migrasi musim gugur, diperkirakan karena pengaruh cuaca (Yamaguchi et al., 2008). Sementara itu, untuk individu lainnya tercatat memiliki durasi yang sangat pendek $(<2$ jam $)$ dan bahkan ada yang hanya melewati pulau saja tanpa singgah. Dari durasi singgah ini maka dapat dipastikan bahwa empat individu Sikep-madu Asia yang direkam jejaknya menggunakan satelit dalam periode 2007-2012 hanya menggunakan 23 pulau yang dianalisis dalam penelitian ini sebagai habitat singgahnya. Untuk menjadi habitat musim dingin (wintering habitat) maka kriterianya adalah memiliki luas diameter habitat $>30 \mathrm{~km}$ dan durasi singgah paling sedikit adalah 24 jam (Higuchi et al. 2005). Pulau Flores secara keseluruhan karena memiliki luas $13.540 \mathrm{~km}^{2}$ selain habitat singgah juga merupakan habitat musim dingin Sikep-Madu Asia berdasarkan data satellite-tracking dari 2 individu di wilayah flores bagian barat dan tengah (Syartinilia et al., 2017). 
Tabel 3 Periode singgah migrasi musim gugur dan musim semi di Flores bagian timur

\begin{tabular}{|c|c|c|c|c|c|c|}
\hline \multirow{2}{*}{$\begin{array}{c}\text { No. } \\
\text { Platform }\end{array}$} & \multicolumn{2}{|c|}{ Migrasi Musim Gugur } & \multirow{2}{*}{$\begin{array}{l}\text { Periode Singgah } \\
\text { Migrasi Musim } \\
\text { Gugur }\end{array}$} & \multicolumn{2}{|c|}{ Migrasi Musim Semi } & \multirow{2}{*}{$\begin{array}{c}\text { Periode Singgah } \\
\text { Migrasi Musim } \\
\text { Semi }\end{array}$} \\
\hline & Datang & Pergi & & Datang & Pergi & \\
\hline \multirow{6}{*}{40757} & 19 Nov 2007 & 22 Nov 2007 & 3 hari & 8 Mar 2008 & 10 Mar 2008 & 2 hari \\
\hline & 8 Nov 2008 & 9 Nov 2008 & 1 hari & 3 Mar 2009 & 5 Mar 2009 & 2 hari \\
\hline & 7 Nov 2009 & 8 Nov 2009 & 1 hari & 4 Mar 2010 & 7 Mar 2010 & 3 hari \\
\hline & 24 Nov 2010 & 25 Nov 2010 & 1 hari & 4 Mar 2011 & 6 Mar 2011 & 2 hari \\
\hline & 15 Nov 2011 & 17 Nov 2011 & 2 hari & 25 Feb 2012 & 26 Feb 2012 & 1 hari \\
\hline & 18 Nov 2012 & 18 Nov 2012 & $<1$ hari & & & \\
\hline 40785 & 20 Nov 2007 & 21 Nov 2007 & 1 hari & 22 Mar 2008 & 24 Mar 2008 & 2 hari \\
\hline \multirow{3}{*}{84425} & 15 Nov 2008 & 15 Nov 2009 & $<1$ hari & 18 Mar 2009 & 19 Mar 2009 & 1 hari \\
\hline & 13 Nov 2009 & 13 Nov 2009 & $<1$ hari & 9 Mar 2010 & 9 Mar 2010 & $<1$ hari \\
\hline & 1 Des 2010 & 5 Des 2010 & 4 hari & & & \\
\hline \multirow{3}{*}{84422} & 17 Nov 2008 & 18 Nov 2008 & 1 hari & 3 Mar 2009 & 5 Mar 2009 & 2 hari \\
\hline & 13 Nov 2009 & - & & & & \\
\hline & 29 Nov 2010 & 1 Des 2010 & 2 hari & & & \\
\hline
\end{tabular}

Durasi singgah yang dilakukan oleh Sikep-madu Asia cenderung lebih lama pada pulau dengan ukuran yang lebih besar dari pulau lainnya. Pulau Flores dan Pulau Lembata merupakan pulau dengan ukuran terbesar yang disinggahi dengan waktu yang lebih lama dari pulau lainnya. Tutupan lahan pada Pulau Flores (Kabupaten Sikka dan Kabupaten Flores Timur) dan Pulau Lembata tersebut juga selaras dengan karakteristik lanskap yang berperan sebagai area berburu bagi Sikep-madu Asia. Pada kedua pulau juga dapat dilihat bahwa variasi tutupan lahan bervegetasi mendominasi yaitu $>95 \%$ dan tutupan lahan berupa hutan dan kebun, memiliki komposisi terbesar yaitu $>60 \%$ pada kedua pulau tersebut (Gambar 6).

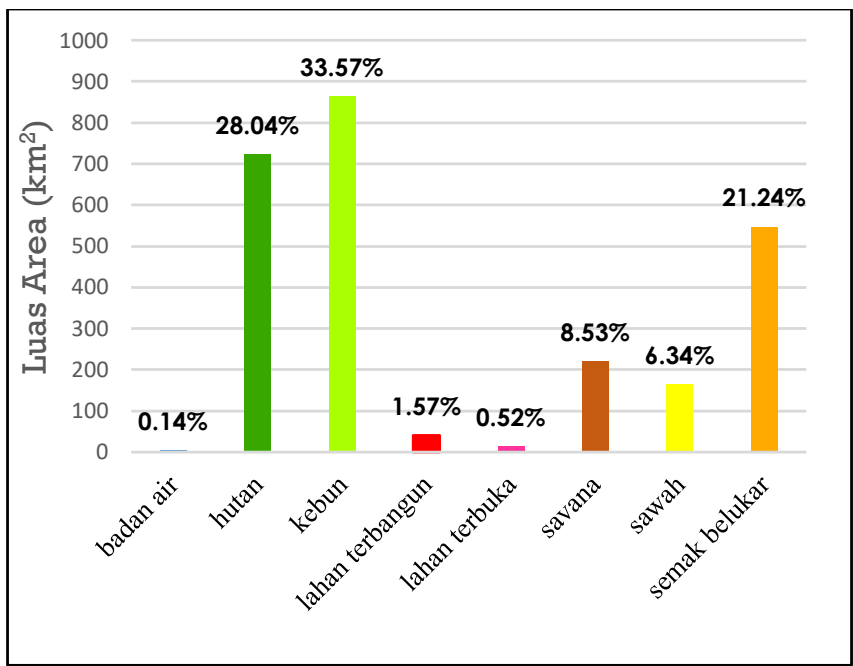

(a)

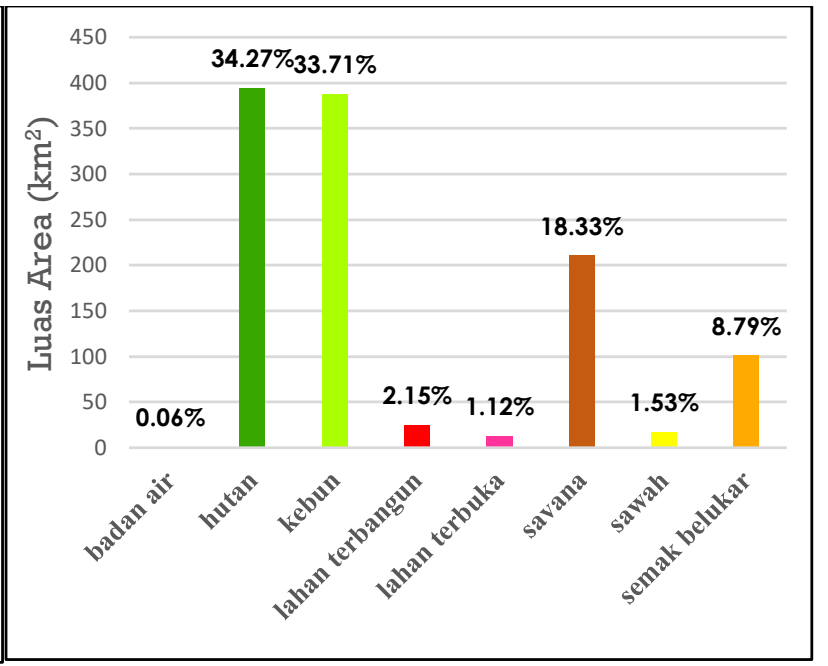

(b)

Gambar 6 Tutupan lahan di Pulau Flores (Kabupaten Sikka \& Kabupaten Flores Timur) (a) dan Pulau Lembata (b)

Ketersediaan makanan merupakan preferensi utama Sikep-madu Asia dalam memilih habitat yang menyediakan pakan utamanya yaitu larva lebah dimana diketahui bahwa Apis dorsata merupakan lebah yang paling banyak ditemukan di Pulau Flores dan biasanya membuat sarang di kawasan hutan dan perkebunan (Syartinilia et al., 2017). 
Selain itu, heterogenitas lanskap yang tinggi dimana ditunjukkan dari keberagaman tipe tutupan lahan yang ada memberikan ketersediaan area berburu pakan alternatif selain larva lebah. Pulau dengan ukuran yang besar dapat menunjang tersedianya keragaman habitat yang tinggi sebagai area berburu Sikep-madu Asia. Ukuran dari suatu pulau maupun patch juga mempengaruhi energi, nutrisi mineral, dan jumlah spesies (Forman dan Godron, 1986).

Flores bagian timur merupakan kawasan yang menjadi habitat singgah oleh Sikep-madu Asia dalam perjalanan migrasi musim gugur maupun migrasi musim semi. Oleh karena itu, lanskap habitat singgah tetap harus dijaga ekosistemnya. Dalam pengelolaannya diharapkan satu daerah dengan daerah lain yang dilintasi Sikep-madu Asia dapat bekerjasama dan menyusun pengelolaan yang terintegrasi, sehingga menjamin keberhasilan perjalanan migrasi Sikep-madu Asia setiap tahunnya.

\section{KESIMPULAN}

Semua pulau di Flores bagian timur dapat berpotensi sebagai habitat singgah (stepping stone) pada migrasi Sikep-madu Asia dari habitat berkembang biak di Jepang menuju habitat musim dingin di Pulau Timor. Berdasarkan data satellite-tracking diketahui bahwa setiap individu yang melewati Flores bagian timur memiliki pola prilaku singgah yang berbeda-beda baik dalam pemilihan pulau untuk habitat singgah dan juga durasi singgahnya. Hal ini dikarenakan kumpulan pulau-pulau kecil di Flores bagian timur dapat menyediakan rute alternatif bagi pergerakan masing-masing individu. Sikep-madu Asia selalu bermigrasi dengan periode waktu yang relatif sama setiap tahunnya. Berdasarkan frekuensi penggunaan pulau dan lamanya singgah, Sikep-madu Asia memiliki preferensi untuk cenderung memilih pulau dengan ukuran yang lebih besar dan juga singgah lebih lama disana yaitu pada Pulau Lembata dan Pulau Flores dibandingkan pulau lainnya. Hal ini diduga karena pulau dengan ukuran lebih besar lebih mendukung keberagaman habitat yang ada sehingga memberi peluang tersedianya pakan yang tinggi.

\section{UCAPAN TERIMA KASIH}

Penelitian ini didukung oleh pendanaan dari Kementerian Lingkungan Hidup, Jepang, (Hiraikeirokaimeichosa, tahun anggaran 2003-2015) dan Kementerian Riset, Teknologi, dan Pendidikan Tinggi (RISTEKDIKTI), Indonesia melalui hibah penelitian desentralisasi Institut Pertanian Bogor yaitu skema Penelitian Unggulan Perguruan Tinggi (PUPT) (Kontrak: 011/SP2H/LT/DRPM/VIII/2017, tahun anggaran 2016-2017).

\section{DAFTAR PUSTAKA}

Bengen DG, Retraubun ASW. 2006. Menguak Realitas dan Urgensi Pengelolaan Berbasis Eko-Sosio Sistem Pulau-Pulau Kecil. Jakarta (ID): Pusat Pembelajaran dan pengembangan Pesisir dan Laut (P4L).

Bildstein KL. 2006. Migrating Raptor of the World. London (GB): Cornell University Press.

Cohn JP. 1999. Tracking wildlife high-tech devises help biologists trace the movement of animals through sky and sea. BioScience. 49: 12-17. doi: 10.1071/WR10211.

Dramstad WE, Olson JD, Forman RT. 1996. Landscape Ecology Principles in Landscape Architecture and Land-Use Planning. Washington DC (US): Island Press.

Forman TT, Godron M. 1986. Landscape Ecology. New York (US): Wiley.

Higuchi H, Shiu H-J, Nakamura H, Uematsu A, Kuno K, Saeki M, Hotta M, Tokita K-I, Moriya E, Morishima E, et al. 2005. Migration of honey buzzards Pernis apivorus based on satellite tracking. Ornithol Sci. 4: 109-115.

Higuchi. 2016. Rekam Jejak Perjalanan Migrasi Burung Menggunakan Teknologi Satellite-Tracking. terjemahan oleh Syartinilia. Bogor (ID): IPB Press. 
Higuchi H, Pierre JP, Krever V, Andronov V, Fujita G, Ozaki K, Goroshko O, Ueta M, Smirensky S, Mita N. 2004. Using a remote technology in conservation: satellite tracking white-naped cranes in Russia and Asia. Conserv Biol. 18: 136-147.

Husni M. 1998. Penataan ruang pulau-pulau kecil di indonesia. Prosiding Seminar dan Lokakarya Pengelolaan Pulau-Pulau Kecil di Indonesia. Jakarta (ID): Kerjasama Departemen Dalam Negeri, Direktorat Pengelolaan Sumberdaya Lahan dan Kawasan - TPSA - BPPT - Coastal Resources Management Project (CRMP) USAID.

Syartinilia, Makalew ADN, Mulyani YA, Higuchi H. 2015. Landscape characteristics derived from satellitetracking data of wintering habitats used by oriental honey buzzards in Borneo. Landscape and Ecological Engineering. 11(1):61-67. doi: 10.1007/s11355-013-0237-4.

Syartinilia, Makalew ADN, Mulyani YA. 2016 Nilai Penting Keberadaan Pulau-Pulau Kecil di Indonesia untuk Keberhasilan Perjalanan Migrasi Sikep Madu Asia (Pernis ptylorhynchus). Di dalam: Higuchi H. Rekam Jejak Perjalanan Migrasi Burung Menggunakan Teknologi Satellite-Tracking. Bogor: IPB Press.

Syartinilia, Al Farisi GH, Higuchi H. 2017. Landscape Characteristics of Oriental Honey Buzzards Wintering in Western Part of Flores Island Based on Satellite-Tracking Data. Prosiding IOP Conf. Series: Earth and Environmental Science.91:012031. doi :10.1088/1755-1315/91/1/012031.

Webster MS, Marra PP, Haig SM, Bensch S, Holmes RT. 2002. Links between worlds: unraveling migratory connectivity. Trends Ecol Evol 17:76-78

Yamaguchi N, Tokita K-I, Uematsu A, Kuno K, Saeki M, Hiraoka E, Uchida K, Hotta M, Nakayama F, Takahashi M, Nakamura H, Higuchi H. 2008. The large-scale detoured migration route and the shifting pattern of migration in oriental honey-buzzards breeding in Japan. J Zool 276:54-62

YKEI. 2014. Raptor Migration Festival. Makalah. Laporan Raptor Migrasi. 